Penultimate draft. Published in the American Journal of Physical Anthropology. DOI:

10.1002/ajpa.24169

\title{
Janus-Faced Race: Is Race Biological, Social, or Mythical?
}

\section{Adam Hochman}

\begin{abstract}
As belief in the reality of race as a biological category among U.S. anthropologists has fallen, belief in the reality of race as a social category has risen in its place. The view that race simply does not exist - that it is a myth — is treated with suspicion. While racial classification is linked to many of the worst evils of recent history, it is now widely believed to be necessary to fight back against racism. In this paper, I argue that race is indeed a biological fiction, but I critique the claim that race is socially real. I defend a form of anti-realist reconstructionism about race, which says that there are no races, only racialized groups - groups mistakenly believed to be races. I argue that this is the most attractive position about race from a metaphysical perspective, and that it is also the position most conductive to public understanding and social justice.
\end{abstract}

\section{KEYWORDS}

race, racism, racialization, racialized groups, social constructionism 


\section{INTRODUCTION}

According to a survey study by Jennifer Wagner and colleagues, U.S. anthropologists have reached a "consensus that there are no human biological races" but agree that "race exists as lived social experiences that can have important effects on health" (2017, p. 318). This distinction between race as a biological and as a social category represents what we might call the two faces of 'race.'

The claim that there is a consensus among anthropologists that there are no human biological races is debatable. A total of $86 \%$ of the survey subjects disagreed with the statement that "The human population may be subdivided into biological races" leaving $14 \%$ who agreed or were uncertain (Wagner et al., 2017, p. 320). To some extent, anthropologists still disagree about which is the true face of "race" (Morning, 2011).

What we know is that anthropologists have largely replaced biological realism about race with social realism about race, at least in some parts of the world (for an international survey, see Lieberman et al., 2003). The view that race is real but social — that races are social groupsis increasingly gaining hegemonic status. Some defend a more nuanced position, according to which the two faces of "race" interact. For instance, Clarence Gravlee (2009) argues that "race" becomes biological through the bio-medical effects of social factors such as racism.

We can see 'race,' then, as Janus-faced. One face is biological. Because belief in the biological reality of race among anthropologists is declining in many regions, we might think of this as the face of race past. The other face is social. This face is much more acceptable today. It is the social face of race. It looks to the future.

Yet there is another perspective on Janus-faced race. Race, like Janus himself, might be a myth. To call race a myth is not to downplay the effects of the idea of race-myths can be immensely powerful—but to insist that "races" themselves do not exist. This view has gone 
out of favor among anthropologists. Eugenia Shanklin, for example, writes that "Continuing to endorse the nonexistence of race (and concomitant inconsequentiality of racism) makes us bedfellows with those who espouse the anti-egalitarian trends we oppose" (1998, p. 673).

In this paper I critique both biological and social accounts of race in favor of the view that race is a myth, and I will show that this view does not entail that racism is inconsequential. Indeed, I argue that the view that there are no races, only racialized groups, is not only the most defensible position in this debate, but that it is also the one most conductive to public understanding and social justice.

I call this view anti-realist reconstructionism about race. 'Anti-realist' because it is the view that race is not real. 'Reconstructionist' because it reconstructs our understanding of the groups understood to be "races." Namely, it is the view that the groups that are commonly understood to be "races" are really racialized groups: groups misunderstood to be biological races.

I begin by arguing against the existence of biological races, focusing on how biological race realists have attempted to weaken the definition of race to accommodate the facts of human biological diversity and why we should not accept watered-down race concepts (see also Hochman, 2016). I also respond to the idea of 'Lewontin's fallacy' (Edwards, 2003), which is commonly appealed to by biological race realists and fellow travelers (Hacking, 2005; Hardimon, 2017; Leroi, 2005; Sesardic, 2010; Tal, 2012; Winegard et al., 2020). I then argue that it is a mistake to interpret the bio-medical effects of racism as, in some way, making "race" biological.

In the following section, I turn to the popular position that "race" is a social reality. This view is sometimes labeled 'social constructionism about race.' I argue that the constructionist metaphor is too ambiguous to be useful and that the view that race is real but social is best understood as claiming either that race is a social kind or that race is a social status that is conferred onto us by others_-a view known as conferralism about race (Ásta, 2018). 
I evaluate both forms of social racial realism and reject them both. I argue that a social kind approach to race inflates the category, so that too many sorts of groups start counting as races. Conferralism about race does not have this problem, but it has another. Sometimes when we are radically mistaken about the nature of a category, we want to be able to reject it as nonreferring. Conferralism is flawed, I argue, because it does not allow this as a possibility, when there are strong reasons to believe that even social racial realism tends to be misleading if not dangerous.

In the final section before the conclusion I turn to the unpopular view that race is a myth. I argue that anti-realist reconstructionism about race-which says that race is not real, but that racialized groups are - is the most attractive position in the race debate. It directly highlights the historicity of racial classification while offering a basis for group identity, recognition, and action. As I will show, the idea that anti-racism demands racial realism is misguided. In fact, anti-realism about race, accompanied by realism about racialized groups, is the most appealing position in the race debate from both a metaphysical and a political perspective.

\section{IS RACE BIOLOGICALLY REAL?}

For the average person on the street, it is hard work not to see "race." We have been so conditioned to see people as coming neatly packaged into a handful of racial groups that it is difficult to unlearn this way of seeing. On the other hand, scientists who specialize in human biological diversity must work hard into order to see "race." The basic facts of human biological diversity just seem incompatible with splitting up the species into a handful of groups (Long \& Kittles, 2009).

Most obviously, human biological diversity is almost entirely clinal, or smooth in its distribution over geographical space (Fujimura et al., 2014; Handley et al., 2007; Serre \& 
Pääbo, 2004). This makes the choice of where one "race" ends and another begins largely arbitrary. Noah Rosenberg and colleagues argue that "small discontinuities occur as geographic barriers are crossed" (2005, p. 661), but other studies with more continuous geographical sampling show no distinct boundaries between populations on either side of physical boundaries, such as the Sahara (e.g. Behar et al., 2010; Tishkoff et al., 2009).

To make matters worse for the biological race realist, human biological diversity is multidimensional. There are countless biological traits that could be used as the basis for racial differentiation. These traits are discordant, meaning that variations in one trait do not, generally, coincide with variations in other traits (Keita et al., 2004). So "racial" classification is not simply arbitrary, it is multiply arbitrary.

One way that biological race realists try to deal with this discord is to correlate different traits, whether they be gene frequencies or craniological measurements. The idea is that, despite the discord between traits, the "races" still have distinctive overall patterns of difference. It turns out that when a certain kind of sampling scheme- one that samples from geographically distant populations and underrepresents sub-Saharan Africans - is used, and a model-based clustering program such as STRUCTURE is programmed to assign individual genotypes to five populations, they will roughly resemble conventional racial categories (Rosenberg et al., 2002). But there is no principled reason to look for five clusters, and when less biased sampling methods are used-e.g. when more samples from sub-Saharan Africans are included-the clusters produced don't resemble anything like conventional racial groupings (see Tishkoff et al., 2009).

One could argue that it doesn't matter whether genetic clusters reflect folk racial categories, which differ from region to region anyway. We don't generally expect science to vindicate "common sense." Indeed, why would we, unless we were somehow invested in the folk categories? 
But moving away from folk racial categories does not help the biological race realist. The folk categories offer a kind of anchor. Biological race realists who defer to the folk do not have to ask, "How many races are there?" because they already have an answer-“As many as people think there are." Once we lose the anchor in folk taxonomy, the question of the number of races becomes a problem for biological race realists, because they must devise a principled way to determine this number.

This may be an impossible task. Consider the classification of skulls by forensic anthropologists. Forensic anthropologists can sort skulls into conventional racial categories, which looks good for biological racial realism. However, they are also able to sort them into much finer grained categories with similar levels of accuracy (Ousley et al., 2009). What justification could there be for calling those from racialized groups the "races" and those from much smaller groups (be they nations, tribes, etc.) something else? Running a reductio ad absurdum argument on these grounds, Stephen Ousley, Richard Jantz, and Donna Freid write, "There are so many possible distinctive biological races that the concept is virtually meaningless" (Ousley et al., 2009, p. 74).

The problem with a conventional racial taxonomy is not that it is impossible to classify people into these groups (given a certain kind of sampling scheme) it is that such a taxonomy does not have any privileged status over countless other ways that we might divide up the species. Once we make the shift from trying to vindicate folk categories to seriously considering whether there are biological races within our species, the need for a definition of race becomes clear. If we want to know whether there are human races, we need to know what human races would be if they existed. Darwin wrote that when it comes to splitting up our species "the term 'sub-species' might here be used with propriety," but predicted that "from long habit the term 'race' will perhaps always be employed” (1871, p. 219). 
It makes sense to think about the term 'sub-species' as the scientific synonym for race. Just like 'race,' 'sub-species' is an attempt at classification below the species level. There has been a significant amount of controversy surrounding the sub-species category (e.g. Wilson \& Brown, 1953; Zink, 2004). However, we can put that controversy to the side for current purposes, because even if we proceed under the assumption that 'subspecies' is an orderly scientific category, there are no human subspecies anyway, according to standard measures.

There are two main methodologies for identifying subspecies. One is to reconstruct the evolutionary history of a species in order to determine whether it fits a tree-like pattern, where subspecies would be represented as branches. As Alan Templeton writes, "Much of the recent scientific literature on human evolution portrays human populations as separate branches on an evolutionary tree." However, he notes that "A tree-like structure among humans has been falsified whenever tested, so this practice is scientifically indefensible," not to mention "socially irresponsible as these pictorial representations of human evolution have more impact on the general public than nuanced phrases in the text of a scientific paper" (Templeton, 2013, p. 262).

The other methodology for identifying subspecies involves searching for populations with sharp genetic boundaries. However, we are all about 99.5\% genetically identical (Levy et al., 2007 ), and only about $5 \%$ to $15 \%$ of the $0.5 \%$ of genetic variation is unique to the populations conventionally called 'races' (Lewontin, 1972; Rosenberg et al., 2002). This is significantly lower than the often-used standard 25\% threshold for subspecies division (Templeton, 2013). We are simply too genetically similar to each other to be divisible into subspecies on this approach.

Human evolutionary history is more interconnected and bush-like than tree-like, and while we have some obvious phenotypic diversity, we are a fairly genetically homogenous species. This is unsurprising, given the relatively young age of our species and our ability to cross 
deserts, mountains, and oceans. While nobody denies the existence of human biological diversity, or that it has some geographical structure, it is not well-captured by the idea of race.

\section{1 "Lewontin's fallacy" revisited}

Biological race realists almost all agree that there are no human subspecies, but they believe that this is compatible with the existence of human races. There are all sorts of ways in which scientists and philosophers of science - particularly the latter-have tried to save race as a biological category (Andreasen, 2004; Glasgow \& Woodward, 2015; Hardimon, 2017; Kitcher, 1999; Pigliucci \& Kaplan, 2003; Spencer, 2019). It is beyond the scope of this paper to respond to them all. Instead, I want to focus on the common claim that anti-realists about race commit “Lewontin’s fallacy” (Hacking, 2005; Hardimon, 2017; Leroi, 2005; Sesardic, 2010; Tal, 2012; Winegard et al., 2020). Indeed, "Lewontin's fallacy" has become the go-to response to antirealism about biological race in the new millennium.

The "fallacy" is named after the geneticist Richard Lewontin, who argued that racial classification is "of virtually no genetic or taxonomic significance" and that "no justification can be offered for its continuance" (Lewontin, 1972, p. 397). Edwards, who coined the term 'Lewontin's fallacy,' believes that Lewontin's “conclusions are based on the old statistical fallacy of analysing data on the assumption that it contains no information beyond that revealed on a locus-by-locus analysis, and then drawing conclusions solely on the results of such an analysis. The 'taxonomic significance' of genetic data," he argues, "in fact often arises from correlations amongst the different loci, for it is these that may contain the information which enables a stable classification to be uncovered" (Edwards, 2003, p. 799). This was precisely the approach taken in the worldwide genetic clustering study discussed above, which was widely interpreted as supporting biological racial realism (Rosenberg et al., 2002). 
There is a glaring problem here: Lewontin did not commit "Lewontin's fallacy." Edwards interprets Lewontin as claiming that it is impossible to classify people racially using genetic data given how genetically similar we all are, and he believes that Lewontin was working under the assumption that correlating different loci would not help in this endeavor. However, Lewontin was not asking whether it was possible to classify people into conventional racial categories using genetic data. Rather, he was interested in the following question: "How much of human diversity between populations is accounted for by more or less conventional racial classification?" (1972, p. 386). He wasn't trying to sort genotypes into racial categories, and as such, he doesn't make the assumption he is accused of making.

Moreover, the assumption Lewontin is accused of making isn't actually false. “Lewontin's fallacy" is not a genuine fallacy. It is possible to sort genotypes into conventional racial categories without correlating different loci, providing that samples are taken from geographically distant groups and enough genetic data is taken (Witherspoon et al., 2007). So not only is Lewontin accused of committing a fallacy he didn't commit, it isn't even a fallacy.

In fact, it is Edwards who is guilty of fallacious reasoning. He assumes - and we might call this Edwards' fallacy - that the ability to classify humans into conventional racial categories vindicates those categories as scientifically meaningful. However, as Koffi Maglo, Tesfaye Mersha and Lisa Martin explain, "in a rational classification of biological organisms, the computational possibility to determine group membership... does not imply that these groups are meaningful according to biological systematic and evolutionary classification criteria" (Maglo et al., 2016, p. 8).

The ability to produce a stable classification scheme implies the existence of some structured variation. Whether that variation is scientifically meaningful or privileged in any way is another question. Biological race realists struggle with this question. Some have retreated to the position Theodosius Dobzhansky defended in the middle of the $20^{\text {th }}$ century, 
according to which, "Races are defined as populations differing in the incidence of certain genes, but actually exchanging or potentially able to exchange genes across whatever boundaries (usually geographic) separate them" (1944, p. 252). For Dobzhansky, "races" are genetically-identifiable-geographical-populations.

The problem with this definition is that there are small local populations that differ in gene frequencies, and they would seem to count as races on this account (Gannett, 2013). To address this problem, Dobzhansky argued that all population differences are racial differences, but that "the races" were just those populations we choose to call races (Dobzhansky, 1962). This view, which admits that racial classification is arbitrary, is endorsed by some contemporary biological race realists. For example, Armand Leroi writes that "there is nothing very fundamental about the major continental races; they're just the easiest way to divide things up. Study enough genes in enough people and one could sort the world's population into 10, 100, perhaps 1000 groups, each located somewhere on the map" (Leroi, 2005, p. 4).

Arguments for the existence of race have started sounding very much like arguments against the existence of race. If there is "nothing very fundamental" about the "major continental races," maybe we should just accept that they don't exist.

How can we decide whether we should just weaken the concept of race, so that it is roughly a synonym for 'population,' as Dobzhansky argued in the mid-20 $0^{\text {th }}$ century and as Leroi argues today? This question raises broad issues about the fate of scientific theories. When should we keep a scientific theory or postulate, and when should it be rejected?

Elsewhere I have argued that we should reject a postulated scientific kind if all three of following conditions are met: (1) a radical change in definition is proposed, (2) the postulated kind is trivialized, and (3) a successful alternative theoretical system, with new terminology, is introduced (Hochman, 2019b). I argue that one condition being met isn't a big deal, necessarily, but all three being met is. For that to take place, we would need to stick with a theoretical posit 
even though the underlying phenomenon is radically different than we thought it was, not nearly as important or interesting as we initially believed, and there is a new way of describing it, associated with scientific advances, that we could — but choose not to- - use instead.

I argue that this is the case with "race" (Hochman, 2019b). In order to accommodate the facts of human biological diversity, biological race realists (1) radically redefine race so that it is no longer synonymous with subspecies, which (2) trivializes the concept, and (3) ignores the fact that population genetics provides an alternative language to describe groups. It would be one thing if "race" were just different to what we thought it was, but the Dobzhansky-style definition of race-as-geographically-identifiable-genetic-population trivializes the category, and is redundant because we can just call populations 'populations' instead.

2.2 Do the bio-medical effects of racism make race real?

A part of the task of this special edition is to act as a guide to navigating the minefield of issues surrounding the intersection of "race," racism, and genetics in anthropology. I want to turn, now, to one way in which anthropologists have conceptualized the connection between "race" and biology that I worry could be misleading. Specifically, I want to discuss Gravlee's popular claim that the bio-medical effects of racism are an example of "how race becomes biology" (Gravlee, 2009, p. 47). I will argue that while this claim is well intentioned, and highlights a phenomenon of great importance, it is ultimately misleading.

It is worth noting that the disagreement between Gravlee and myself is largely semantic. In fact, when he elaborates on his view, I wholeheartedly agree. Gravlee explains that when he writes that "race becomes biology" he means that "Social inequalities shape the biology of racialized groups, and embodied inequalities perpetuate a racialized view of human biology" (Gravlee, 2009, p. 48). This is absolutely correct. An example of this phenomenon is the higher 
pre-term birth rate among those racialized as Black in the U.S., which has been attributed to environmental factors such as racism (Leimert \& Olson, 2020).

My concern is not with the claim that racism can "shape the biology of racialized groups," but rather that this phenomenon can be described as an example of how "race becomes biology." Race can only become biology_or anything - if race is real. As Naomi Zack explains, "nonexistent entities cannot be causes, effects, or objects in relationships with things that do exist" (2001, p. 447). While Gravlee's discussion of racialized groups is not metaphysically invested in the reality of race, his talk of "race" becoming biology assumes that race is real. In what sense does Gravlee believe this to be true?

"I define race," Gravlee explains, "as a worldview" (2009, p. 48). We can now make sense of his claim that race becomes biology: race is real as a worldview that has biological effects, which function to further entrench that worldview. I worry that this definition of race sets the bar for the reality of race too low, and risks being misinterpreted. Astrology is a worldview, and so by analogy astrology would seem to count as real. But imagine if someone were to ask you whether you think that astrology is real. It is unlikely that they would be asking you whether you think astrology counts as a worldview. No, they want to know whether you think that astrology is an accurate worldview.

Similarly, the question about the reality of race is not whether there exists a racialized lens through which people interpret the world. Rather, the question about the reality of race is whether "races" themselves exist in some substantive sense. Talk of "race" becoming biology ought to be interpreted in this light. To determine the reality of race, we need to give race a substantive definition. An example of this is the definition of race as subspecies. If subspecies is the scientific synonym for race, then the only way to make "race" a biological reality would be through the formation of human subspecies. The medical effects of racism have not created human subspecies, so they do not make race a biological reality. 
Another way to make sense of the idea that the medical effects of racism make race a biological reality would be to define races as meaningful biological groups distinguishable by their health profiles. Nobody, as far as I am aware, proposes such a definition of race. There are thousands of diseases that could potentially form the basis of such a classification scheme, and they do not only correlate with exposure to racism, but also with age, sex, geographical ancestry, socioeconomic status, lifestyle, and so on. Choose two different diseases as a basis for classification and you will likely end up with two very different classification schemes. The idea that "races" are groups distinguishable by their health profiles is unworkable.

The bio-medical effects of racism are indeed biological, but they do not make race a biological reality (Msimang, 2020). The bio-medical effects of racism are just that-biomedical effects of racism. Highlighting these effects of racism is of great importance, but as Gravlee (2009) himself shows, we can do this without committing ourselves metaphysically to racial realism. The bio-medical effects of racism affect racialized groups-groups mistakenly believed to be biological races_-not "races" themselves.

The idea of race is so deeply entrenched that we can easily make metaphysical commitments to racial realism without even realizing, and I want to warn against this. For instance, it is common to think about health disparities between racialized groups as racial disparities. Offering an alternative perspective, Shannon Sullivan argues that when it comes to "health differences related to race ... just as accurate as labeling them racial disparities would be to call them racist disparities" (Sullivan, 2013, p. 192).

While for Sullivan the phrase "racist disparities" is just as accurate as the phrase "racial disparities," the former is more accurate than the latter if there are no races. If we think of race as a biological category, and there are no biological races, then it does not make sense to talk about any sort of "racial" disparities whatsoever. There would be disparities between racialized groups - groups mistakenly believed to be races_-but no racial disparities. 
In this section I have interpreted race as a biological category, and I have argued that it fails to refer. However, rather than concluding from the failures of race as a biological category that race does not exist, anthropologists — and indeed race theorists generally — tend to claim that race exists in some social sense. Indeed, recall that Wagner and colleagues find evidence of a consensus among U.S. anthropologists that "race exists as lived social experiences" (2017, p. 318). In the following section, I critically analyze the move to social realism about race.

\section{IS RACE SOCIALLY REAL?}

The claim that "race exists as lived social experiences" is difficult to interpret. The experience of being racialized — of being classified as belonging to this or that "race"—is certainly real. The experiences of living in a racist society are also real. What does the claim that "race" itself exists add to the claims that racialization and racism are real, and that they have a wide range of effects? What does the claim that "race exists as lived social experiences" actually mean?

\subsection{Race as a "social construct"}

Many of those who defend the view that race is real but social call themselves 'social constructionists.' Perhaps if we can understand what it means to be a social constructionist, we will be able to interpret the claim that race is real in some social sense.

It turns out that there are many ways that social constructionism can be applied to 'race.' I believe that there are at least five versions of social constructionism about race in the literature:

1. "Antirealism about race often takes the form of a version of social constructivism: the claim that race is merely a social construct" (Nanay, 2010, p. 256). 
2. "Social constructivism about races holds that races are socially real, that is, that races should be identified with socially constructed properties, or social kinds" (Diaz-Leon, 2015, p. 547).

3. "The account of race that I have sketched...is a social constructivist account of race. On this view, being of a certain race is to have a certain social status in a context" (Ásta, 2018, p. 106).

4. "Races might quite literally be social constructs, in that our patterns of acculturation maintain the genetic distinctiveness of different racial groups" (Kitcher, 1999, pp. 246247).

5. "... race is a "social construct," a way of categorizing people that changes over time and across countries" (Reich, 2018).

On view $\# 1$, race is taken to be non-existent. On view \#2, race is described as a social kind. On view \#3, race is described as a social status. On view \#4, race is taken to be a biological kind, produced by social forces. View \#5 is quiet on the metaphysics of race-it simply claims that racial classifications change over time and differ between contexts.

As the quotes above demonstrate, social constructionists defend all the major metaphysical positions about race: anti-realism about race, social realism about race, even biological realism about race. Social constructionism about race is so ambiguous that it is virtually meaningless. $\# 1$ is incompatible with $\# 2, \# 3$, and \#4: if race is not real, it is not socially or biologically real. Position \#5, on the other hand, is very flexible - it is compatible with all the other views. 
Gravlee puts it well: "The fact that the race concept is a relatively recent historical development bound to a particular cultural context has no bearing on whether it is a good approximation of reality" (2013, p. 36).

One might respond by saying that some of these views are not really social constructionist. However, it is unclear on what basis this could be argued. According to the most influential definition of social constructionism, the view entails that " $\mathrm{X}$ need not have existed, or need not be at all as it is. $\mathrm{X}$, or $\mathrm{X}$ as it is at present, is not determined by the nature of things; it is not inevitable" (Hacking, 1999, p. 6). All five versions of social constructionism about race fit this definition, and so seem to count as genuine forms of social constructionism.

While each particular social constructionist view about race is coherent, they do not form a coherent whole, as some are mutually exclusive. As such, if we want to understand what it means to say that "race exists" in some social sense, social constructionism about race as a whole is not going to give us the answer. It may also be of limited educational value, given its ambiguity. However, two versions of social constructionism about race do seem to offer a justification for the claim that race is real, but social. That is view \#2, the position that race is a social kind, and view \#3, the position that race is a social status. I will discuss these in turn.

\subsection{Race as a social kind}

The view that race is a social kind is the most popular position in the philosophical literature on 'race' (Diaz-Leon, 2015; Haslanger, 2012; Mallon, 2017; Mills, 1998; Msimang, 2019, 2019; Pierce, 2014; Sundstrom, 2002a; Taylor, 2013). The idea of social kinds can be

understood by way of analogy with kinds from the physical sciences, like gold. As Ronald Sundstrom writes, "the kind 'gold' is unified by an atomic number," and, "Similarly, a human [or social] kind is real when unified by a significant social relation" (2002a, p. 94). To make 
this more precise, kinds are distinguished by a set of significant and unique properties and relations. The chemical kind gold is not only unified by the atomic number 79 , this atomic number distinguishes gold from other chemical kinds.

There are certainly significant social relations between racialized groups. For instance, there are economic, political, and legal inequalities between groups classified by "race" (Smedley \& Smedley, 2005). However, this does not speak to the question of uniqueness. There are also economic, political, and legal inequalities between groups distinguished by class, gender, age, etc. If we define "races" as groups between which there are economic, political, and legal inequalities then we would have to conclude that groups defined by class, gender, and age are races, which seems absurd. If race were a social kind, there would have to be social relations that distinguish race from other categories, just as the atomic number 79 distinguishes gold from other chemical kinds.

It may be helpful to offer a clear example of a social kind: slavery. As a provisional definition, a person is a slave if they are treated as the property of another, whom they are forced to obey. 'Slave' is a social kind because slavery can be identified purely on the basis of a unique social relation. We can imagine a different understanding of slavery, where a person would be a slave if and only if they were explicitly labelled as a slave. In that case, slavery would not be a social kind, because slaves could not be identified on the basis of their social relations with others. A person who was made to work without pay and who lost many of their personal freedoms, but whom was not explicitly classified as a slave, would not count as a slave. The intuition that such an approach constitutes a fundamental misunderstanding of slavery is driven by an implicit acceptance of a social kind approach to the subject.

Moving back to 'race,' Phila Msimang offers what I believe to be the best attempt at a social kind definition of race - a definition that focuses exclusively on social relations, and tries to identify those unique to the subject. Msimang argues that the "characteristics of a social race 
are that they are stereotyped groups" about which there is a "presumption that racial identity is fixed" and a "belief that race is a genealogical and heritable kind of group belonging" (Msimang, 2019, p. 15). While this is an excellent attempt to identify the social properties and relations specific to "race," it is ultimately unsuccessful, because it lets too many sorts of groups count as "races."

Msimang's three conditions of stereotyping, fixity, and genealogy are met for many sorts of groups that we wouldn't usually think of as races. Consider the following example: Scottish coalminers in the $17^{\text {th }}$ and $18^{\text {th }}$ centuries (Duckham, 1969). An Act of Parliament in 1606 ordained that coalminers be bound in a condition of permanent serfdom to their employers. The fixity condition was therefore enshrined in law. The children of the miners were generally regarded as serfs from birth, and this was certainly true of those males who had passed into puberty working in the mines. As such, the genealogy condition was also met. The reader will not be surprised that there were negative stereotypes about the miners, who were stripped of human rights and made to do hard physical labour in difficult conditions. As such, it appears that the Scottish coalminers would constitute a "race" on Msimang's social kind account of race.

This is an example of what I've called the specificity problem or the inflation problem (Hochman, 2017). When race is defined as a social kind it loses its conceptual specificity: it becomes inflated, and more and more categories start counting as "races." 'Race' also loses its historical specificity on a social kind definition (Hochman, 2019a). While racial thinking is usually understood to have its origins in modernity or shortly beforehand in fifteenth-century Spain, on a social kind account its origins are hazy. For example, the coloni of the Roman Empire were hereditary farmers, and they would count as a race on Msimang's theory, in much the same way as the Scottish coalminers in more recent times. I don't believe that the issue is 
with Msimang's particular definition, but rather with the entire project of redefining race as a social kind.

\subsection{Conferralism about race}

"Race" may not be a social kind, but it might be social in some other sense. Ásta (2018) offers an alternative to a social kind theory of race, according to which race is a social status that is conferred onto us by others. She calls this view 'conferralism,' and it would seem to solve the inflation problem. Only those groups believed to be races would actually be races. The Scottish coalminers were not widely believed to constitute a race, and so they would not count as a race on the conferralist framework. Nor would the coloni of the Roman Empire.

According to conferralism, there is a base property that conferrers are trying to track in their conferral. As Ásta explains, "The individuals in question may or may not have this base property, but what is important is that they are taken to have it and get conferred on them a social status on that basis" $(2018$, p. 3$)$.

Herein lies the problem with conferralism about race. On this approach, we could never be wrong enough about "race" to say that it doesn’t exist. Ásta explains that the "base" property that institutions are attempting to track is "biological race" (2018, p. 96). Yet, given the failure of biological racial realism, we may want to conclude that races do not exist, only racialized groups - groups mistakenly believed to be races.

"Race" is sometimes thought to be real in a similar way to money (Taylor, 2000). Money is only valuable because enough of us believe it to be valuable. Similarly, "race" is believed to be real precisely because we give "it" social meaning. However, there is an important difference between the two categories. When we collectively agree that money is valuable it becomes valuable, but when groups were racialized they did not take on the key properties they 
were believed to possess. For this reason, we may not want to think of racialization as a racemaking process.

Consider the following analogy. Conferralism would seem to entail that the women hung for being witches were all actually witches! It does not matter that they did not have the base property they were assumed to have - supernatural powers, or pacts with the devil. The social status 'witch' was conferred onto them, and that made them all witches.

This goes against the common intuition that the women hung for being witches were not really witches (or that only those that practiced wicca were witches). Some may not share this intuition. However, a normative argument may be persuasive for those that have what philosophers call "deviant intuitions." It would be dangerous to call women witches in contexts in which "witches" are believed to be evil and are executed on this basis. That would be a way to get innocent people killed. On purely pragmatic grounds, it would be wiser and kinder to differentiate between "witches" and women falsely accused of being witches.

I believe that the same logic ought to be applied to "race." Just as we tend to distinguish between "witches" and women falsely accused of being witches, we ought to distinguish between "races" and groups mistakenly believed to be races. The problem with conferralism is that it does not recognize a distinction between a social status that refers and a social status that fails to refer. Yet just as it is important to be able to distinguish between failed and successful posits in the physical sciences (e.g. electric effluvia vs electricity), it is important to be able to reject categories that are supposed to describe the social world when they are misleading in important ways. In the following section, I argue that 'race' is one such category, and that for this reason we ought to distinguish between "races"-which don't exist—and racialized groups-which do. 


\section{IS RACE A MYTH?}

Anti-realism about race is treated with great suspicion among many anthropologists and race theorists more generally. Racial realism is widely considered to be necessary in order to fight racism, and racial identities are also important to many people. In this section, I defend antirealism about race against its critics. I argue that we should abandon racial realism in favor of anti-realist reconstructionism about race, the view that there are no races, only racialized groups. Such a view is entirely compatible with anti-racism, and it also offers a solid basis for group recognition, action, and identity.

Explaining why anti-realism about race has developed a bad reputation, Sundstrom describes "a naive form of "racial" skepticism that has become popular in U.S. conservative politics" (2002b, p. 194). On this naïve interpretation of racial skepticism or anti-realism, there are no "races" and so there is no need to address and redress "race-based" injustice. For defenders of this view, affirmative action or reparations programs that seek to improve the lives of members of particular "races" are hopelessly flawed because "races" do not exist. This is of course a convenient position for those who are not committed to fighting racism.

If anti-realism about race were to entail that affirmative action and reparations programs ought to be abolished then we would have a conflict between our best metaphysical account of race and normative commitments that most of us hold: that racism is wrong and that the wrongs of racism ought to be addressed.

However, there is a way to avoid the apparent tension between anti-realism about race and anti-racism. Races may not exist, but racialized groups - groups misunderstood to be racesare real. If racism harms racialized groups, rather than "races," then affirmative action and reparations programs — indeed any anti-racist initiative — can targeted racialized groups, rather than "races." As Shawn Wandile Mavundla explains, "The distinction between race and 
racialised individuals or groups is very instructive because it not only enables the anti-realist ... to continue to talk and write policies about racialised individuals and groups, but it can also be instrumental in correcting some racial [or, rather, racist] injustices that were perpetrated through the concept of race in the past, and pursue social and economic justice going forward" (2019, p. 224).

These terms — racialization and racialized group — have already gained some currency in the literature. However, they are not used in a consistent fashion. While some distinguish the concept of the racialized group from the concept of race, the terms are often used as synonyms. This is sometimes explicit, for example when Sally Haslanger writes that "races [in the U.S. context] are racialized groups" (2019, p. 26; see also Msimang, 2019).

Instead of using 'race' and 'racialized group' as synonyms, there are good reasons to distinguish them and to see 'racialized group' as a conceptual tool for anti-realists about race. Doing so solves the problems I have identified with social approaches to "race." Recall the inflation problem, which I've argued is endemic to social kind definitions of race. I made the case that social kind definitions of race inflate the concept, allowing too many sorts of groups to count as races. The idea of the racialized group solves this problem of conceptual inflation. A racialized group is a group that is misinterpreted as a biological race. So while the Scottish coalminers would seem to count as a "race" according to Msimang's (2019) social kind theory of race, they do not count as a racialized group, because the coalminers were not generally understood to constitute a biological race.

Conferralism would also solve the inflation problem, but at a high cost. As I've explained, conferralism entails that all social labels that receive uptake (and influence how people are treated) successfully refer. This is a problem because just as we want to be able to reject categories meant to describe the physical world, we should be able to reject categories meant to describe the social world. I take this to be uncontroversial. For example, we want to reject 
any notion of there being a "master race" (Hochman, 2015; Kyllingstad, 2014). But what about "race" itself: why prefer the concept of the racialized group?

As I mention above, the groups labelled as "races" did not have the base properties they were assumed to have (e.g. they were not subspecies, they did not form a hierarchy). This is not necessarily a problem, because how people conceptualize categories can change over time. In the case of 'race,' though, we have reason to doubt the elasticity of the category. As Chike Jeffers observes, "There is good reason to think that it is hard to separate talk of race from traditional biological essentialism" (Jeffers, 2019, p. 44). Despite decades of public education that 'race' is a social rather than a biological category, research has shown that most nonspecialists still understand race as a biological property, and that such an understanding of race is linked with having racist attitudes (Brown et al., 2009; Condit et al., 2004; Donovan, 2014; Lynch et al., 2008; Shulman \& Glasgow, 2010). This means that when social race realists talk about "race" they will likely be interpreted as talking about biological race, even if that is not their intention.

Robert Miles warns of this problem when he writes that race-talk "is particularly problematic when 'race relations' sociology reports its findings and conclusions to politicians, the media and the public in a historical context in which the nineteenth century idea of 'race' continues to be reproduced" (1988, p. 10). Race-talk by academics and scientists is likely to be misunderstood by the public, and these misunderstandings are likely to be harmful. If race-talk is understood to refer to biological "races" that form a natural hierarchy, for instance, then this talk is highly dangerous. It doesn't matter what the speaker has in mind; what matters is how they are interpreted.

The idea of the racialized group has the clear advantage here. As J.L.A. Garcia explains, while a 'race' is something one supposedly has, "racialization is something that is done to a group, by some social agent, at a certain time, for a given period, in and through various 
processes, and relative to a particular social context" (2003, p. 285). As such, the language of racialization directly highlights the historical and contextual nature of racial classification in a way that race-talk does not. As Lawrence Blum argues, "The term "racialized groups" is preferable as a way of acknowledging that some groups have been created by being treated as if they were races, while also acknowledging that "race" in its popular meaning is entirely false" (Blum, 2002, p. 160). I go further here, because I have argued not only that "“"race" in its popular meaning is entirely false" but also that there is no good way to justify a more technical notion of race.

A study by Julie Shulman and Joshua Glasgow (2010) found that racist attitudes are positively correlated not only with biological racial realism, but also with social racial realism. As they explain,

This study found new evidence for the existence of such a contingent connection between believing in race and having more racist attitudes, as realists were more likely than anti-realists to have racist attitudes or lack racial tolerance (which may be unsurprising, as it would seem difficult to have racist attitudes if one doesn't believe in race). Interestingly, however, while being a realist is an indicator that one is more likely to have these racist attitudes, no differences in racist attitudes were found between those with wholly biological theoretical intuitions about race and those with other intuitions about race. These results suggest that there is some (nonessential) connection between racial realism and some kinds of racist attitudes, but also that racist attitudes do not differ in relation to different realist conceptions of race. (Shulman \& Glasgow, 2010, p. 255)

Race scholars have not been very successful in changing peoples' understanding about race from a biological to a social category. This study suggests that this may be the wrong strategy anyway - that anti-realism may be more effective in countering racism, at least on the individual level. And when anti-realism about race is paired with realism about racialized groups it is also a suitable tool in the fight against institutional racism. 
While Sundstrom is right to warn us of naïve racial skepticism or anti-realism, there is a more sophisticated form of the position that can address the misuse of anti-realism about race by politicians and policymakers. However, another worry about anti-realism about race remains, concerning how the anti-realist treats "racial" identities.

The survey study discussed above allowed for open-ended responses, and Jayne Ifekwunigwe and colleagues (2017) provide some of these, along with their own qualitative analysis. One of the surveyed anthropologists explains their worry about anti-realism about race in relation to identity as follows: "Among the strongest proponents of racial categories are black people who idealized their "race" (e.g., "Black is beautiful") to gain the strength to stand up to discrimination and marginalization" (Reference \#378C, Ifekwunigwe et al., 2017, p. 428).

It would be a serious problem with anti-realist reconstructionism if it were incompatible with Black pride. However, it is not committed to the view that Black people do not exist, only to the view that Black people do not constitute a "race." For the anti-realist reconstructionist, Black people constitute a racialized group. Black pride is pride in a racialized group.

Another surveyed anthropologist writes that "Race ... has reality in terms of how lives are lived and experienced - I cannot tell Oprah or Nelson Mandela or my black neighbor that race doesn't exist. Each of their lives tells narratives of its true force, and it is that force (of this human-made concept) that we can change." (Reference \#160A, Ifekwunigwe et al., 2017, p. 428). Anti-realism about race is presented here as unspeakable. Of course, it would be offensive to suggest that racism is not real. However, anti-realism about race does not imply the nonexistence of racism. And as I explain above, it is perfectly compatible with black identities, as the so-called races can be understood as racialized groups.

Anti-realism about race is not in tension with personal identity in the way it might initially appear — it just needs to be combined with realism about racialized groups. However, Glasgow worries that this view "would require that those who care about being, say, black have to stop 
thinking of themselves as members of a race ... and instead conceive of themselves as members of erroneously racialized groups, so that their identities are, in some sense, fraudulent" (2009, p. 150). On this view, identifying with a racialized group would involve buying into a lie. It would be a sort of identity demotion.

In response to Glasgow, Blum explains why identification with one or more racialized groups does not involve fraudulence of any kind:

\footnotetext{
To recognize that one's racial[ized] ancestors, and perhaps oneself, have been treated as if they possessed certain genetic deficiencies that they did not in fact possess does not involve having a falsehood-based identity. One's sense of peoplehood is indeed bound up with having been racialized, and racialization can be embraced by those who are racialized as a way to contest the inferiorization to which one or members of one's group are subject. The 'fraudulence' lies in the beliefs that have rationalized one's people's plight, not in the nature of the identity itself. (2010: 314$)$
}

It is not fraudulent, nor is it an identity demotion, to identify with a racialized group, or indeed with more than one. Glasgow may have found this response convincing, as he defends the view that there are no races, only racialized groups, in a recent book (Glasgow, 2019).

The concerns about anti-realism about race are important, and worth taking seriously. However, I've argued that they can be dealt with by adopting a reconstructionist approach. The worry that anti-realism about race is incompatible with "racial" justice can be dealt with if we see racism as a problem that affects racialized groups, rather than "races." And the worry that anti-realism about race strips people of their identities can be dealt with if we reinterpret those identities in terms of racialization, rather than "race." Given the failings of both biological and social accounts of race, and the benefits of adopting the category of the racialized group, it may be time to consign the idea of race to the dustbin of history's bad ideas. 


\section{CONCLUSION}

Referring to the RACE project - a major public education project led by physical anthropologists - the former president of the American Anthropological Association Alan Goodman explained that "The idea was to develop a public education project about the intersections of race, racism and human biological and genetic variation. We wanted to change the public debates to get them beyond the simple dichotomy that race is either real or not real to consider in a more serious fashion the varieties of ways in which race sometimes is real and sometimes isn't”'(2007, p. 117).

Like Goodman, I believe that the simple dichotomy between race as real or not real is insufficient. But unlike Goodman, I do not believe that we ought to reject the dichotomy. Rather, we ought to make an additional distinction: between 'race' and 'racialized group.'

Simple distinctions have an obvious benefit: they are easy to understand. The idea that race is sometimes real and sometimes not real, real in some senses but not others, and sometimes real is some senses but not others, is quite a complicated message to send to the public. It risks being misunderstood. The view that races do not exist, but that racialized groups-groups falsely believed to be races_-do exist, is much more straightforward.

This view - anti-realist reconstructionism about race — has the benefit of simplicity. If my arguments are good, it also has the benefit of being true. Race is not real in any substantive sense, not even sometimes. Racial classification is unjustifiable from a biological perspective, and race does not become a biological reality through the bio-medical effects of racism, any more than the bio-medical effects of witch-hunts make "witches" biologically real.

Racial classification is also unjustifiable from a social perspective. While the claim that race exists as a social category seems intuitively true, the matter is not as simple as it sounds. Racial classification is real, and racism is real, but the claim that race itself is real in some social sense 
makes an extra claim. This claim is best interpreted as the idea that race is a social kind or that race is a social status conferred onto us by others.

As I have argued, social kind definitions of race inflate the category beyond recognition, allowing too many sorts of groups to count as "races." Conferralism suffers from a different problem. It entails that we could never be so wrong about a social category that we ought to reject it from our ontology. But sometimes we do get things really wrong, and "race" is a good example of a category where we have gotten things so wrong, and where the consequences of this have been and continue to be so catastrophic, that we ought to consider rejecting the category as non-referring. That is something conferralism cannot accommodate, and this is a fundamental flaw in the theory.

Given the failings of both biological and social realism about race, we ought to conclude that race is a myth. Some worry that anti-realism about race is incompatible with anti-racism. However, as S.O.Y. Keita and colleagues explain, "The absence of "races" does not mean the absence of racism, or the structured inequality based on operationalized prejudice used to deprive people who are deemed to be fundamentally biologically different of social and economic justice. The "no biological race" position does not exclude the idea that racism is a problem that needs to be addressed" (2004, p. S18).

Yet we do need ways to talk about the groups mistakenly believed to be races. We need ways of talking about the groups that have been - and continue to be- the victims, the perpetrators, and the beneficiaries of racism. This is something that the category of the racialized group provides.

It also provides a basis for group recognition, action, and identity. As an added benefit, the language of racialization and racialized groups directly highlights the historicity of racial classification, where the language of race does not. In contexts where 'race' is still understood to be a biological category, the continued use of racial classification by anthropologists and 
other specialists is likely to be understood as giving a scientific stamp of approval for biological racial realism, even when that is not the intended message.

The continued use of racial classification reflects "the tenacious and adhesive quality of socially constructed ideas" and shows how "through their historical usage these ideas become common sense notions that resist deconstruction" (Darder \& Torres, 1997, p. 93). Indeed, the survey by Wagner and colleagues demonstrates that while belief in race as a biological category is down among U.S. anthropologists, belief that race exists as a social category is up. I have argued that race is indeed a biological illusion, but I have critiqued the claim that race is socially real. Racism is real, and racialized groups are real, but race itself is a myth.

The implication for anthropologists and other specialists is that we should educate the public on the non-existence of races and the reality of racialization, racialized groups, and racism. The term 'race' is now often used as a euphemism for 'racism.' But what is "race-based violence" if not racist violence? What is a "racial attack" if not a racist attack? When we say that we need to talk about race, do we not mean that we need to talk about racism? Outdated criticisms of anti-realism about race characterize the position as avoiding the reality of "race." However, it is better understood as an invitation to face the realities of racialization and racism, while avoiding the reification of race.

\section{Acknowledgements}

I would like to thank Connie Mulligan and Jennifer Raff for inviting me to contribute to this special edition. Thanks also to Jennifer Mensch, Frances Olive, an anonymous editorial board member, and two anonymous reviewers for their helpful comments on an earlier version of this paper. This work was funded by a Discovery Early Career Researcher Award (DE190100411). 


\section{Conflict of Interest}

The author declares no conflict of interest.

\section{References}

Andreasen, R. (2004). The cladistic race concept: A defense. Biology and Philosophy, 19(3), $425-442$.

Ásta. (2018). Categories We Live By: The Construction of Sex, Gender, Race, and Other Social Categories. Oxford University Press.

Behar, D. M., Yunusbayev, B., Metspalu, M., Metspalu, E., Rosset, S., Parik, J., Rootsi, S., Chaubey, G., Kutuev, I., Yudkovsky, G., Khusnutdinova, E. K., Balanovsky, O., Semino, O., Pereira, L., Comas, D., Gurwitz, D., Bonne-Tamir, B., Parfitt, T., Hammer, M. F., ... Villems, R. (2010). The genome-wide structure of the Jewish people. Nature, 466(7303), 238-242.

Blum, L. (2002). “I'm not a racist, but...” The moral quandary of race. Cornell University Press.

Brown, T. N., Akiyama, M. K., White, I. K., Jayaratne, T. E., \& Anderson, E. S. (2009). Differentiating Contemporary Racial Prejudice from Old-Fashioned Racial Prejudice. Race and Social Problems, 1, 97-110.

Condit, C. M., Parrott, R. L., Harris, T. M., Lynch, J., \& Dubriwny, T. (2004). The Role of "Genetics" in Popular Understandings of Race in the United States. Public Understanding of Science, 13(3), 249-272.

Darder, A., \& Torres, R. D. (1997). From race to racism: The politics of "race" language in “postmodern education.” New Political Science, 19(1-2), 89-95. 
Darwin, C. (1871). The Descent of Man, and Selection in Relation to Sex. D. Appleton and Company.

Diaz-Leon, E. (2015). In Defence of Historical Constructivism about Races. Ergo, an Open Access Journal of Philosophy, 2(21), 547-562.

Dobzhansky, T. (1944). On species and races of living and fossil man. American Journal of Physical Anthropology, 2(3), 251-265.

Dobzhansky, T. (1962). Comment. Current Anthropology, 3(3), 279-280.

Donovan, B. M. (2014). Playing with fire? The impact of the hidden curriculum in school genetics on essentialist conceptions of race. Journal of Research in Science Teaching, $51(4), 462-496$.

Duckham, B. F. (1969). Serfdom in eighteenth century Scotland. History, 54(181), 178-197.

Edwards, A. W. F. (2003). Human genetic diversity: Lewontin's fallacy. Bioessays, 25(8), 798-801.

Fujimura, J. H., Bolnick, D. A., Rajagopalan, R., Kaufman, J. S., Lewontin, R. C., Duster, T., Ossorio, P., \& Marks, J. (2014). Clines Without Classes How to Make Sense of Human Variation. Sociological Theory, 32(3), 208-227.

Gannett, L. (2013). Theodosius Dobzhansky and the genetic race concept. Studies in History and Philosophy of Biological and Biomedical Sciences, 44, 250-261.

Garcia, J. L. A. (2003). Three scalarities: Racialization, racism, and race. Theory and Research in Education, 1(3), 283-302.

Glasgow, J. (2009). A theory of race. Routledge.

Glasgow, J. (2019). Race an Illusion or a (Very) Basic Reality? In What Is Race? Four Philosophical Views. Oxford University Press.

Glasgow, J., \& Woodward, J. M. (2015). Basic racial realism. Journal of the American Philosophical Association, 1(3), 449-466. 
Goodman, A., \& Garfinkle, R. (2007). RACE: Are We So Different? Museums \& Social Issues, 2(1), 117-131.

Gravlee, C. C. (2009). How Race Becomes Biology: Embodiment of Social Inequality. American Journal of Physical Anthropology, 139, 47-57.

Gravlee, C. C. (2013). Race, biology, and culture: Rethinking the connections. In J. Hartigan (Ed.), Anthropology of Race: Genes, Biology, and Culture (pp. 21-41). SAR Press.

Hacking, I. (1999). The social construction of what? Harvard University Press.

Hacking, I. (2005). Why race still matters. Daedalus, 134(1), 102-116.

Handley, L. J. L., Manica, A., Goudet, J., \& Balloux, F. (2007). Going the distance: Human population genetics in a clinal world. TRENDS in Genetics, 23(9), 432-439.

Hardimon, M. O. (2017). Rethinking Race: The Case for Deflationary Realism. Harvard University Press.

Haslanger, S. (2012). Resisting reality: Social construction and social critique. Oxford University Press.

Haslanger, S. (2019). Tracing the Sociopolitical Reality of Race. In J. Glasgow, S. Haslanger, C. Jeffers, \& Q. Spencer, What Is Race? Four Philosophical Views. Oxford University Press.

Hochman, A. (2015). Of Vikings and Nazis: Norwegian contributions to the rise and the fall of the idea of a superior Aryan race. Studies in History and Philosophy of Biological and Biomedical Sciences, 54, 84-88.

Hochman, A. (2016). Race: Deflate or pop? Studies in History and Philosophy of Biological and Biomedical Sciences, 57, 60-68.

Hochman, A. (2017). Replacing Race: Interactive Constructionism about Racialized Groups. Ergo, 4(3), 61-92. 
Hochman, A. (2019a). Is "Race" Modern? Disambiguating the Question. Du Bois Review: Social Science Research on Race, 16(2), 647-665.

Hochman, A. (2019b). Race and Reference. Biology \& Philosophy, 34(32), 1-22.

Ifekwunigwe, J. O., Wagner, J. K., Yu, J.-H., Harrell, T. M., Bamshad, M. J., \& Royal, C. D. (2017). A Qualitative Analysis of How Anthropologists Interpret the Race Construct. American Anthropologist, 119(3), 422-434.

Jeffers, C. (2019). Cultural Constructionism. In What Is Race? Four Philosophical Views. Oxford University Press.

Keita, S. O. Y., Kittles, R. A., Royal, C. D. M., Bonney, G. E., Furbert-Harris, P., Dunston, G. M., \& Rotimi, C. N. (2004). Conceptualizing human variation. Nature Genetics, $36(11), \mathrm{S} 17-\mathrm{S} 20$.

Kitcher, P. (1999). Race, ethnicity, biology, culture. In L. Harris (Ed.), Racism (pp. 87-120). Humanity Books.

Kyllingstad, J. R. (2014). Measuring the Master Race: Physical Anthropology in Norway, 1890-1945. Open Book Publishers.

Leimert, K., \& Olson, D. (2020). Racial disparities in pregnancy outcomes: Genetics, epigenetics, and allostatic load. Current Opinion in Physiology, 13, 155-165.

Leroi, A. L. (2005). A family tree in every gene. Journal of Genetics, 84(1), 3-6.

Levy, S., Sutton, G., Ng, P. C., Feuk, L., Halpern, A. L., Walenz, B. P., Axelrod, N., Huang, J., Kirkness, E. F., Denisov, G., Lin, Y., MacDonald, J. R., Pang, A. W. C., Shago, M., Stockwell, T. B., Tsiamouri, A., Bafna, V., Bansal, V., Kravitz, S. A., ... Venter, J. C. (2007). The Diploid Genome Sequence of an Individual Human. PLOS Biology, $5(10), 2113-2144$. 
Lewontin, R. (1972). The Apportionment of Human Diversity. In T. Dobzhansky, M. K. Hecht, \& W. C. Steere (Eds.), Evolutionary Biology (Vol. 6, pp. 381-398). Meredith Publishing Company.

Lieberman, L., Kirk, R. C., \& Littlefield, A. (2003). Exchange across difference: The status of the race concept. Perishing paradigm: Race-1931-99. American Anthropologist, 105(1), 110-113.

Long, J., \& Kittles, R. (2009). Human genetic diversity and the nonexistence of biological races. Human Biology, 81(5-6), 777-798.

Lynch, J., Bevan, J., Achter, P., Harris, T., \& Condit, C. M. (2008). A preliminary study of how multiple exposures to messages about genetics impact on lay attitudes towards racial and genetic discrimination. New Genetics and Society, 27(1), 43-56.

Maglo, K. N., Mersha, T. B., \& Martin, L. J. (2016). Population Genomics and the Statistical Values of Race: An Interdisciplinary Perspective on the Biological Classification of Human Populations and Implications for Clinical Genetic Epidemiological Research. Frontiers in Genetics, 7(22), 1-13.

Mallon, R. (2017). Social Construction and Achieving Reference. Noûs, 51(1), 113-131.

Mavundla, S. W. (2019). Interactive constructionism: A more preferable anti-realist approach to the metaphysics of race. South African Journal of Philosophy, 38(2), 219-225.

Miles, R. (1988). Beyond the 'Race' Concept: The Reproduction of Racism in England. Sydney Studies in Society and Culture, 4, 7-31.

Mills, C. W. (1998). Blackness visible: Essays on philosophy and race. Cornell University Press.

Morning, A. (2011). The nature of race: How scientists think and teach about human difference. University of California Press. 
Msimang, P. (2019). Racializing races: The racialized groups of interactive constructionism do not exclude races. Ergo, 6(1), 1-30.

Msimang, P. (2020). Medicine, anti-realism and ideology: Variation in medical genetics does not show that race is biologically real. SATS, 20(2), 117-140.

Nanay, B. (2010). Three Ways of Resisting Racism. The Monist, 93(2), 255-280.

Ousley, S., Jantz, R., \& Freid, D. (2009). Understanding race and human variation: Why forensic anthropologists are good at identifying race. American Journal of Physical Anthropology, 139(1), 68-76.

Pierce, J. (2014). A realist metaphysics of race: A context-sensitive, short-term retentionist, long-term revisionist approach. Lexington Books.

Pigliucci, M., \& Kaplan, J. M. (2003). On the concept of biological race and its applicability to humans. Philosophy of Science, 70(5), 1161-1172.

Reich, D. (2018). How Genetics Is Changing Our Understanding of 'Race.' The New York Times.

Rosenberg, N. A., Mahajan, S., Ramachandran, S., Zhao, C., Pritchard, J. K., \& Feldman, M. W. (2005). Clines, clusters, and the effect of study design on the inference of human population structure. PLoS Genetics, 1(6), 660-671.

Rosenberg, N. A., Pritchard, J. K., Weber, J. L., Cann, H. M., Kidd, K. K., Zhivotovsky, L. A., \& Feldman, M. W. (2002). Genetic structure of human populations. Science, 298(5602), 2381-2385.

Serre, D., \& Pääbo, S. (2004). Evidence for gradients of human genetic diversity within and among continents. Genome Research, 14, 1679-1685.

Sesardic, N. (2010). Race: A social destruction of a biological concept. Biology and Philosophy, 25(2), 143-162. 
Shanklin, E. (1998). The Profession of the Color Blind: Sociocultural Anthropology and Racism in the 21st Century. American Anthropologist, 100(3), 669-79.

Shulman, J. L., \& Glasgow, J. (2010). Is race-thinking biological or social, and does it matter for racism? An exploratory study. Journal of Social Philosophy, 41(3), 244-259.

Smedley, A., \& Smedley, B. (2005). Race as biology is fiction, racism as a social problem is real. American Psychologist, 60(1), 16-26.

Spencer, Q. (2019). A More Radical Solution to the Race Problem. Aristotelian Society Supplementary Volume, 93(1), 25-48.

Sullivan, S. (2013). Inheriting Racist Disparities in Health Epigenetics and the Transgenerational Effects of White Racism. Critical Philosophy of Race, 1(2), 190218.

Sundstrom, R. R. (2002a). Race as a human kind. Philosophy \& Social Criticism, 28(1), 91115.

Sundstrom, R. R. (2002b). “Racial” nominalism. Journal of Social Philosophy, 33(2), 193210.

Tal, O. (2012). The cumulative effect of genetic markers on classification performance: Insights from simple models. Journal of Theoretical Biology, 293, 206-218.

Taylor, P. C. (2000). Appiah's uncompleted argument: W.E.B. Du Bois and the reality of race. Social Theory and Practice, 26(1), 103-128.

Taylor, P. C. (2013). Race: A Philosophical Introduction. Polity.

Templeton, A. (2013). Biological races in humans. Studies in History and Philosophy of Biological and Biomedical Sciences, 44(3), 262-271.

Tishkoff, S. A., Reed, F. A., Friedlaender, F. R., Ehret, C., Ranciaro, A., Froment, A., Hirbo, J. B., Awomoyi, A. A., Bodo, J. M., \& Doumbo, O. (2009). The genetic structure and history of Africans and African Americans. Science, 324(5930), 1035-1044. 
Wagner, J. K., Yu, J.-H., Ifekwunigwe, J. O., Harrell, T. M., Bamshad, M. J., \& Royal, C. D. (2017). Anthropologists' views on race, ancestry, and genetics. American Journal of Physical Anthropology, 162, 318-327.

Wilson, E. O., \& Brown, W. (1953). The subspecies concept and its taxonomic application. Systematic Zoology, 2(3), 97-111.

Winegard, B., Winegard, B., \& Anomaly, J. (2020). Dodging Darwin: Race, evolution, and the hereditarian hypothesis. Personality and Individual Differences, 160, 109915.

Witherspoon, D. J., Wooding, S., Rogers, A. R., Marchani, E. E., Watkins, W. S., Batzer, M. A., \& Jorde, L. B. (2007). Genetic similarities within and between human populations. Genetics, 176(1), 351-359.

Zack, N. (2001). Philosophical aspects of the "AAA Statement on "Race." Anthropological Theory, 1(4), 445-465.

Zink, R. M. (2004). The role of subspecies in obscuring avian biological diversity and misleading conservation policy. Proceedings of the Royal Society of London. Series B: Biological Sciences, 271(1539), 561-564. 